Pacific Journal of Mathematics

PROBABILITIES OF WIENER PATHS CROSSING 


\title{
PROBABILITIES OF WIENER PATHS CROSSING DIFFERENTIABLE CURVES
}

\author{
C. PARK AND S. R. Paranjape
}

Let $\{W(t) ; t \geqq 0\}$ be the standard Wiener process. The probabilities $P\left[\sup _{0 \leqq t \leqq r} W(t) \geqq b\right]$ and $P\left[\sup _{0 \leqq t \leqq T} W(t)-a t \geqq b\right]$ are well known. This paper gives the probabilities of the type $P\left[\right.$ sup $\left._{0 \leqq t \leqq T} W(t)-f(t) \geqq b\right]$ for a large class of differentiable functions $f(t)$ by the use of integral equation techniques.

1. Introduction. Let $\{W(t), t \geqq 0\}$ be the standard Wiener process such that (i) $P[W(0)=0]=1$, (ii) $E W(t)=0$ for all $t \geqq 0$, and (iii) $\operatorname{Cov}[W(s), W(t)]=\min (s, t)$. It is well known that for $b \geqq 0$

$$
P\left[\sup _{0 \leqq t \leqq T} W(t) \geqq b\right]=2 P[W(T) \geqq b]=2 \Psi\left(b T^{-1 / 2}\right)
$$

where

and that

$$
\Psi(x)=(2 \pi)^{-1 / 2} \int_{x}^{\infty} \exp \left(-u^{2} / 2\right) d u
$$

$$
\begin{aligned}
& P\left[\sup _{0 \leqq t \leqq T} W(t)-a t \geqq b\right] \\
= & \Psi\left[(a T+b) T^{-1 / 2}\right]+\exp (-2 a b) \Phi\left[(a T-b) T^{-1 / 2}\right],
\end{aligned}
$$

where $\Phi(x)=1-\Psi(x)$.

The identity (1.1) can be found in [2:392], [5:286], and [11:256] while the identity (1.2) can be found in [6], [7:348-349], and [9:8082]. Doob [3:397-399] gives a very interesting proof of (1.2) for $T=\infty$ case only. Shepp's proof for (1.2) is based on his transformation theorem in [7]. Cameron-Martin translation theorem in [1] also gives the same result using Shepp's argument.

The main purpose of this paper is to find the probability $P\left[\sup _{0 \leqq t \leqq T} W(t)-f(t) \geqq b\right]$ for a large class of functions $f(t)$ differentiable in (0,T], which is a generalization of the results (1.1) and (1.2). Durbin [4] gave an integral equation whose solution would be the required probability. However, it turned out to be that his integral equation could not be solved analytically, and hence he presented a numerical approximation method. After that Smith [8] introduced some new techniques to obtain an approximation for the probability. The present authors' integral equation gives explicit expression for the solution, while Durbin's and Smith's do not.

2. Statement of the result and proof.

THEOREM. For each $T>0$ let $f(t)$ be continuous on $[0, T]$, 
differentiable in $(0, T)$, and satisfy $\left|f^{\prime}(t)\right| \leqq C / t^{p}(p<1 / 2)$ for some constant $C$. Then the probability $P\left[\sup _{0 \leqq t \leqq T} W(t)-f(t) \geqq b\right] \equiv F(T)$ is one if $f(0)+b \leqq 0$, and otherwise it is given as the unique continuous solution of the integral equation

$$
F(T)=2 \Psi\left[(f(T)+b) T^{-1 / 2}\right]-2 \int_{0}^{T} F(t) M(T, t) d t,
$$

where

$$
\Psi(x)=(2 \pi)^{-1 / 2} \int_{x}^{\infty} \exp \left(-u^{2} / 2\right) d u
$$

and

(2.2) $M(z, t)=\left\{\begin{array}{cl}(2 \pi)^{-1 / 2} \frac{\partial}{\partial t} \int_{-\infty}^{[f(z)-f(t)](z-t)^{-1 / 2}} \exp \left(-u^{2} / 2\right) d u,(0 \leqq t<z \leqq T) \\ 0, \quad(0 \leqq z \leqq t \leqq T) .\end{array}\right.$

More precisely for $f(0)+b>0$

$$
\begin{aligned}
& P\left[\sup _{0 \leqq t \leqq T} W(t)-f(t) \geqq b\right] \\
= & h(T)+\sum_{n=1}^{\infty} 4^{n} \int_{0}^{T} K_{n}(T, t) h(t) d t,
\end{aligned}
$$

where

$$
\begin{aligned}
h(T) & =2 \Psi\left[(f(T)+b) T^{-1 / 2}\right]-4 \int_{0}^{T} M(T, t) \Psi\left[(f(t)+b) t^{-1 / 2}\right] d t, \\
K_{1}(T, t) & =\int_{t}^{T} M(T, z) M(z, t) d z,
\end{aligned}
$$

and

$$
K_{n+1}(T, t)=\int_{t}^{T} K_{n}(T, z) K_{1}(z, t) d z .
$$

Proof. If $f(0)+b \leqq 0$, then since $W(0)=0$ a.s., it is obvious that the probability is one. Now, let $\tau=\tau(\omega)$ be the first hitting time of the curve $f(t)+b$ by the sample path $W(t, \omega)$, that is to say that $W(\tau, \omega)=f(\tau)+b$, and if $0 \leqq t<\tau$, then $W(t, \omega)<f(t)+b$. If $W(t, \omega)$ never reaches the curve $f(t)+b$, then we simply set $\tau=\infty$. Thus

$$
\begin{aligned}
F(T)= & P[W(T) \geqq f(T)+b] \\
& +P\left[\sup _{0 \leqq s \leqq T} W(s)-f(s) \geqq b, W(T)<f(T)+b\right] .
\end{aligned}
$$

Using the fact that $P[\tau \leqq t]=P\left[\sup _{0 \leqq s \leqq t} W(s)-f(s) \geqq b\right] \equiv F(t)$ and the notation in the theorem, we obtain 


$$
\begin{aligned}
F(\mathrm{~T})= & \Psi\left[(f(T)+b) T^{-1 / 2}\right] \\
& +\int_{0}^{T} P[W(T)<f(T)+b \mid \tau=t] d F(t) \\
= & \Psi\left[(f(T)+b) T^{-1 / 2}\right] \\
& +\int_{0}^{T} P[W(T)-W(t)<f(T)-f(t) \mid \tau=t] d F(t) .
\end{aligned}
$$

Since the increment $W(T)-W(t)$ is independent of the condition $\tau=t$, it follows that

$$
\begin{aligned}
F(T)= & \Psi\left[(f(T)+b) T^{-1 / 2}\right] \\
& +\int_{0}^{T} \Phi\left[(f(T)-f(t))(T-t)^{-1 / 2}\right] d F(t),
\end{aligned}
$$

where $\Phi(x)=(2 \pi)^{-1 / 2} \int_{-\infty}^{x} \exp \left(-u^{2} / 2\right) d u . \quad$ As $\lim _{t \uparrow T}[f(T)-f(t)](T-$ $t)^{-1 / 2}=0$, integration by parts yields (interpreting the integral in improper sense)

$$
F(T)=\Psi\left[(f(T)+b) T^{-1 / 2}\right]+\frac{1}{2} F(T)-\int_{0}^{T} F(t) M(T, t) d t,
$$

from which (2.1) follows.

To solve the integral equation (2.1) rewrite $M(z, t)$ by the use of (2.2)

$$
M(z, t)=\left\{\begin{array}{cl}
(2 \pi)^{-1 / 2}(z-t)^{-1 / 2} & {\left[-f^{\prime}(t)+\frac{f(z)-f(t)}{2(z-t)}\right] \exp \left\{-\frac{[f(z)-f(t)]^{2}}{2(z-t)}\right\}} \\
& \text { if } 0 \leqq t<z \leqq T \\
0 & \text { if } 0 \leqq z \leqq t \leqq T .
\end{array}\right.
$$

Apparently $M(z, t)$ is not square integrable on $[0, T]^{2}$. Hence the integral equation (2.1) can not be solved by usual methods for Volterra integral equations of the second kind (see Tricomi [10, pp.10-15]). However, using the expression (2.1) for $F(t)$ in the right-hand side of (2.1), we can rewrite (2.1) as:

$$
F(T)=G(T)-2 \int_{0}^{T} M(T, z)\left[G(z)-2 \int_{0}^{z} F(t) M(z, t) d t\right] d z,
$$

where $G(T)=2 \Psi\left[(f(T)+b) T^{-1 / 2}\right]$. Thus the change of order of integration gives

$$
\begin{aligned}
F(T)= & G(T)-2 \int_{0}^{T} M(T, t) G(t) d t \\
& +4 \int_{0}^{T} F(t)\left[\int_{t}^{T} M(T, z) M(z, t) d z\right] d t .
\end{aligned}
$$

Now, using the conditions on $f(T)$ in the theorem and the Mean 
Value Theorem, we obtain from (2.4) with suitable constants $C_{1}$ and $C_{2}$

$$
\begin{aligned}
& \left|\int_{t}^{T} M(T, z) M(z, t) d z\right| \\
\leqq & C_{1} \int_{t}^{T}(T-z)^{-1 / 2}(z-t)^{-1 / 2}\left[\left|f^{\prime}(z)\right|+\frac{C}{2} z^{-p}\right]\left[\left|f^{\prime}(t)\right|+\frac{C}{2} t^{-p}\right] d z \\
\leqq & C_{2} t^{-p} \int_{t}^{T}(T-z)^{-1 / 2}(z-t)^{-1 / 2} z^{-p} d z .
\end{aligned}
$$

The substitution $z=t+(T-t) u$ in the above yields

$$
\begin{aligned}
\left|\int_{t}^{T} M(T, z) M(z, t) d z\right| & \leqq C_{2} t^{-p} \int_{0}^{1}(1-u)^{-1 / 2} u^{-1 / 2}[u T+(1-u) t]^{-p} d u \\
& \leqq C_{2} t^{-p} T^{-p} \int_{0}^{1}(1-u)^{-1 / 2} u^{-1 / 2} u^{-p} d u \\
& \leqq \text { const. }) t^{-p} T^{-p}
\end{aligned}
$$

Thus the kernel $\int_{t}^{T} M(T, z) M(z, t) d z$ in the integral equation (2.5) is indeed square integrable for any $p<1 / 2$, and hence the integral equation has a unique continuous solution for $F(T)$, and the solution is given by (2.3) (see Tricomi [10, pp. 5-8]).

REMARK. In some special cases of $f(t)$ the integral equation in the theorem can be solved more directly.

Case 1. If $f(t) \equiv c$ in the theorem, then $M(T, t) \equiv 0$ and hence $F(T)=2 \Psi\left[(c+b) T^{-1 / 2}\right]$ which agrees with (1.1).

Case 2. If $f(t)=a t$, then

$$
\begin{aligned}
M(T, t) & =(2 \pi)^{-1 / 2} \frac{\partial}{\partial t} \int_{-\infty}^{a \sqrt{T-t}} \exp \left(-u^{2} / 2\right) d u \\
& =\frac{-a}{2(2 \pi)^{1 / 2}}(T-t)^{-1 / 2} \exp \left[-a^{2}(T-t) / 2\right] \equiv N(T-t), 0 \leqq t<T .
\end{aligned}
$$

If we set $G(T) \equiv 2 \Psi\left[(a T+b) T^{-1 / 2}\right]$, then the integral equation becomes

$$
F(T)=G(T)-2 \int_{0}^{T} F(t) N(T-t) d t .
$$

Taking the Laplace transform $\left(L[F(T)]=\int_{0}^{\infty} e^{-s T} F(T) d T\right)$ of both sides, we get

$$
L[F(T)]=L[G(T)]-2 L[F(T)] L[N(T)],
$$




$$
\begin{aligned}
L[F(T)] & =L[G(T)] /\{1+2 L[N(T)]\} \\
& =s^{-1} \exp \left[-a b-b\left(2 s+a^{2}\right)^{1 / 2}\right] .
\end{aligned}
$$

Therefore,

$$
F(T)=1-\Phi\left[(a T+b) T^{-1 / 2}\right]+\exp (-2 a b) \Phi\left[(a T-b) T^{-1 / 2}\right]
$$

which agrees with (1.2).

\section{REFERENCES}

1. R. H. Cameron and W. T. Martin, On transformations of Wiener integrals under a general class of linear transformations, Ann. Math., 45 (1944), 386-396.

2. J. L. Doob, Stochastic Processes, John Wiley \& Sons, Inc., 1953.

3. - Heuristic approach to the Kolmogorov-Smirnov theorems, Ann. Math. Stat., 20 (1949), 393-403.

4. J. Durbin, Boundary-crossing probabilities for the Brownian motion and poisson processes and techniques fo computing the power of the Kolmogorov-Smirnov test, J. Appl. Prob., 8 (1971), 431-453.

5. I. I. Gikhman and A. V. Skorokhod, Introduction to the Theory of Random Processes, W. B. Saunders Co., 1969.

6. S. Malmquist, On certain confidence contours for distribution functions, Ann. Math. Stat., 25 (1954), 523-533.

7. L. A. Shepp, Radon-Nikodym derivatives of Gaussian measures, Ann. Math. Stat., 37 (1966), 321-354.

8. C. S. Smith, A note on boundary-crossing probabilities for the Brownian motion, J. Appl. Prob., 9 (1972), 857-861.

9. L. Takacs, Combinatotial Methods in the Theory of Stochastic Processes, John Wiley \& Sons, Inc., 1967.

10. F. G. Tricomi, Integral Equations, Interscience Publishers, Inc., 1957.

11. H. G. Tucker, A Graduate Course in Probability, Academic Press, 1967.

Received April 12, 1973 and in revised form January 20, 1974.

Miami University 



\section{PACIFIC JOURNAL OF MATHEMATICS}

\section{EDITORS}

RICHARD ARENS (Managing Editor)

University of California

Los Angeles, California 90024

\section{J. DUGUNDJI}

Department of Mathematics University of Southern California Los Angeles, California 90007

D. Gilbarg and J. Milgram

Stanford University

Stanford, California 94305

University of Washington
Seattle, Washington 98105

ASSOCIATE EDITORS
E. F, BECKENBACH
B. H. NEUMANN
F. WOLF
K. Yoshida

\section{SUPPORTING INSTITUTIONS}

\author{
UNIVERSITY OF BRITISH COLUMBIA \\ CALIFORNIA INSTITUTE OF TECHNOLOGY \\ UNIVERSITY OF CALIFORNIA \\ MONTANA STATE UNIVERSITY \\ UNIVERSITY OF NEVADA \\ NEW MEXICO STATE UNIVERSITY \\ OREGON STATE UNIVERSITY \\ UNIVERSITY OF OREGON \\ OSAKA UNIVERSITY
}

\author{
UNIVERSITY OF SOUTHERN CALIFORNIA \\ STANFORD UNIVERSITY \\ UNIVERSITY OF TOKYO \\ UNIVERSITY OF UTAH \\ WASHINGTON STATE UNIVERSITY \\ UNIVERSITY OF WASHINGTON \\ * * * * \\ AMERICAN MATHEMATICAL SOCIETY \\ NAVAL WEAPONS CENTER
}

The Supporting Institutions listed above contribute to the cost of publication of this Journal, but they are not owners or publishers and have no responsibility for its content or policies.

Mathematical papers intended for publication in the Pacific Journal of Mathematics should be in typed form or offset-reproduced, (not dittoed), double spaced with large margins. Underline Greek letters in red, German in green, and script in blue. The first paragraph or two must be capable of being used separately as a synopsis of the entire paper. Items of the bibliography should not be cited there unless absolutely necessary, in which case they must be identified by author and Journal, rather than by item number. Manuscripts, in duplicate if possible, may be sent to any one of the four editors. Please classify according to the scheme of Math. Rev. Index to Vol. 39. All other communications to the editors should be addressed to the managing editor, or Elaine Barth, University of California, Los Angeles, California, 90024.

100 reprints are provided free for each article, only if page charges have been substantially paid. Additional copies may be obtained at cost in multiples of 50 .

The Pacific of Journal Mathematics is issued monthly as of January 1966. Regular subscription rate: $\$ 72.00$ a year (6 Vols., 12 issues). Special rate: $\$ 36.00$ a year to individual members of supporting institutions.

Subscriptions, orders for back numbers, and changes of address should be sent to Pacific Journal of Mathematics, 103 Highland Boulevard, Berkeley, California, 94708.

PUBLISHED BY PACIFIC JOURNAL OF MATHEMATICS, A NON-PROFIT CORPORATION

Printed at Kokusai Bunken Insatsusha (International Academic Printing Co., Ltd.), 270, 3-chome Totsuka-cho, Shinjuku-ku, Tokyo 160, Japan.

Copyright (C) 1973 by Pacific Journal of Mathematics Manufactured and first issued in Japan 


\section{Pacific Journal of Mathematics}

\section{Vol. 53, No. $2 \quad$ April, 1974}

Kenneth Abernethy, On characterizing certain classses of first countable spaces by

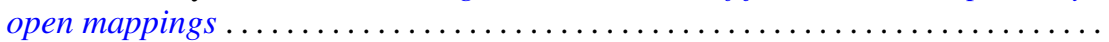

Ross A. Beaumont and Donald Lawver, Strongly semisimple abelian groups .......

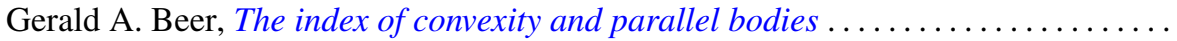

Victor P. Camillo and Kent Ralph Fuller, On Loewy length of rings ..............

Stephen LaVern Campbell, Linear operators for which $T^{*} T$ and $T T^{*}$ commute.

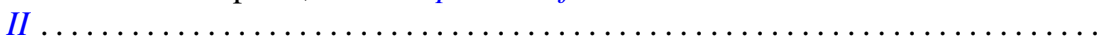

Charles Kam-Tai Chui and Philip Wesley Smith, Characterization of a function by

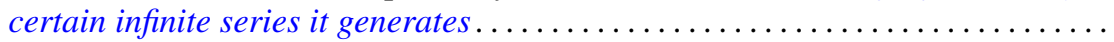

Allan L. Edelson, Conjugations on stably almost complex manifolds . ...........

Patrick John Fleury, Hollow modules and local endomorphism rings . . ..........

Jack Tilden Goodykoontz, Jr., Connectedness im kleinen and local connectedness in

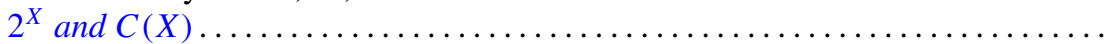

Robert Edward Jamison, II, Functional representation of algebraic intervals .......

Athanassios G. Kartsatos, Nonzero solutions to boundary value problems for

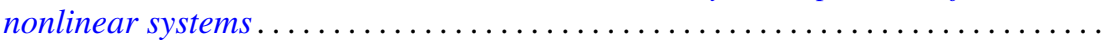

Soon-Kyu Kim, Dennis McGavran and Jingyal Pak, Torus group actions on simply

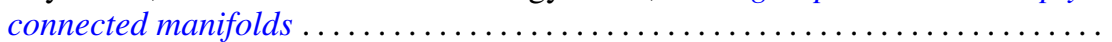

David Anthony Klarner and R. Rado, Arithmetic properties of certain recursively

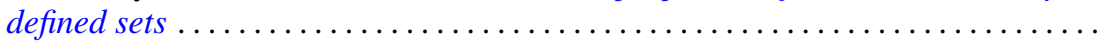

Ray Alden Kunze, On the Frobenius reciprocity theorem for square-integrable

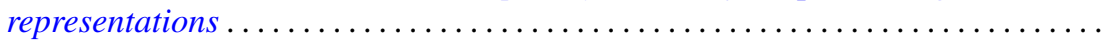

John Lagnese, Existence, uniqueness and limiting behavior of solutions of a class of differential equations in Banach space...

Teck Cheong Lim, A fixed point theorem for families on nonexpansive mappings Lewis Lum, A quasi order characterization of smooth continua

Andy R. Magid, Principal homogeneous spaces and Galois extensions . .

Charles Alan McCarthy, The norm of a certain derivation ..... . .

Louise Elizabeth Moser, On the impossibility of obtaining $S^{2} \times S^{1}$ by elementary surgery along a knot. .

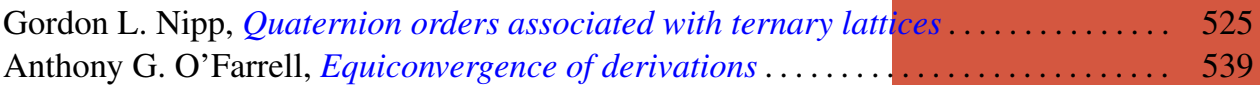

Dorte Olesen, Derivations of $A W^{*}$-algebras are inner . . . . . . . . . . . . . . . 555

Dorte Olesen and Gert Kjærgaard Pedersen, Derivations of $C^{*}$-algebras have

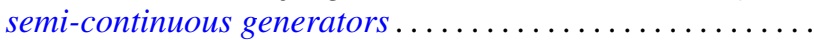

Duane O’Neill, On conjugation cobordism.

Chull Park and S. R. Paranjape, Probabilities of Wiener paths crossing differentiable

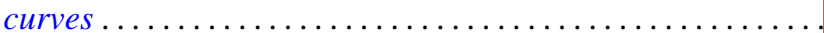

Edward Ralph Rozema, Almost Chebyshev subspaces of $L^{1}(\mu$;

Lesley Millman Sibner and Robert Jules Sibner, A note on the Atiyah-Bott fixed

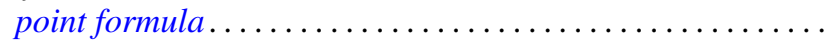

Betty Salzberg Stark, Irreducible subgroups of orthogonal groups generated by

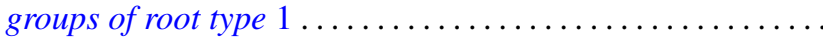

N. Stavrakas, A note on starshaped sets, $(k)$-extreme points and the half ray

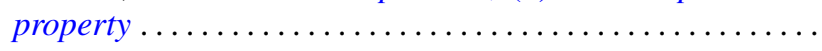

Carl E. Swenson, Direct sum subset decompositions of $Z \ldots \ldots$ 